\title{
IGF-1R/IR Inhibitor KW-2450
}

National Cancer Institute

\section{Source}

National Cancer Institute. IGF-1R/IR Inhibitor KW-2450. NCI Thesaurus. Code C84871.

An orally bioavailable inhibitor of insulin-like growth factor 1 receptor (IGF-1R) and insulin receptor (IR) tyrosine kinases with potential antineoplastic activity. IGF-1R/IR inhibitor KW2450 selectively binds to and inhibits the activities of IGF-1R and IR, which may result in the inhibition of tumor cell proliferation and the induction of tumor cell apoptosis. IGF-R1 and IR tyrosine kinases, overexpressed in a variety of human cancers, play significant roles in the stimulation of cellular proliferation, oncogenic transformation, and suppression of apoptosis. 